Periodica Polytechnica Architecture, 49(1), pp. 92-97, 2018

\title{
Hidden Modernism: Architecture Theory of the Socialist Realist Gap
}

\author{
Borbála Jász ${ }^{1 *}$ \\ ${ }^{1}$ Department of Philosophy and History of Science, Faculty of Economic and Social Sciences, \\ Budapest University of Technology and Economics, H-1521 Budapest, P.O.B. 91, Hungary \\ * Corresponding author, e-mail: jasz.borbala@filozofia.bme.hu
}

Received: 01 March 2018, Accepted: 11 April 2018, Published online: 28 May 2018

\begin{abstract}
The aim of this paper is to clarify and exemplify the difference between modern, socialist realism and late modern in architecture. In the general pre-theoretical use of these terms, this distinction is often blurred; a unified expression, socialist realism, is used for all the aforementioned terms. This paper will examine a possible answer for this phenomenon by using examples from different areas of eastern-Central Europe, especially from Hungarian architecture.

The paper first focuses on the façadism of socialist realism in the architecture of eastern-Central Europe. Following this, it shows that the architectural tendencies of classical modernism did not disappear in this period; they were just not explicitly manifest in case of public buildings for example. Finally, the paper argues that after this socialist realist gap, architectural theory and planning tendencies of the interwar period returned and continued, especially the work of Le Corbusier.
\end{abstract}

Keywords

Socialist Realism, façadism, Le Corbusier, interwar period

\section{Introduction}

Restructured power relations in the countries of eastern-Central Europe after WW2 also left their mark on architecture. Historical forms returned to the form-language of architecture after the classical modernism of the interwar period. The Soviet worldview was the dominant ideological system with a motto: "socialist by content, national by form". A specific type of building of this era emerged with a neoclassical façade but with an underlying modernist structure: party houses, university buildings and complete Potemkin cities were constructed this way. The era of socialist realism lasted only for a few years and came to a sudden halt on the 31st December 1954. After that, a new age emerged: the era of house blocks.

Historical forms returned to the form-language of architecture with the Marxian worldview. However, the Khrushchevian architectural turn grounded a new way of architectural thinking in the 1960s with a strong focus on social responsibility. This was the age of house factories and house blocks, and it was based on scientific planning and on opposing individualism. The ideology of house factories is a return to the classical science-based modernist architectural theory in the interwar period. The experimental housing estates were built based on scientific theories. This was, in fact, a common approach all around Europe, in the West and the East alike.

The housing block system in Eastern Europe, however, was not a new phenomenon. The scientifically planned 'machinised city' is called Le Corbusier's Radiant City [Villa Radieuse, 1930-33], where the usage of the city is coded in its very own structure. There are lots of similarities in the city of the first machine age of Le Corbusier and the socialist housing block system. The ideal block house was a type of Unité d'Habitation (1947-52), which opened the door for the style of new brutalism. The functional and scientifically supported socialist housing block (made of concrete) was the continuation of new brutalism. The usage of the rooms in a blockhouse was planned scientifically, similarly to the planned construction of machinised cities.

\section{Presented image vs real content - the façadism of socialist realism}

The Potemkin city phenomenon was first mentioned in the 18th century when Grigorij Alexandrovics Patyomkin designed staged villages to create the illusion of a wealthy 
peasantry for Catherine the Great. Adolf Loos turned this phenomenon into a theory in connection with the critique of historicist architecture at the beginning of the $20^{\text {th }}$ century. Loos criticised the lack of function and the overuse of decorative elements of architecture [Stilarchitektur]. This critique was also extended to urban design.

It appears that after WW1 and WW2, the same changes can be seen in function architecture, especially in its social aspects. After WW1, in eastern-Central Europe, mansions were developed based on western European examples. After WW2, historicist architecture was stigmatised by the modernist architects as aristocratic, dysfunctional and outdated. Besides planning and constructing the buildings themselves, modernist architects also determined the interior design. The aim was to create the concept of standardised houses with serial built-in furniture - similarly to the aims of architecture after WW1. After WW2, modernism continued; this also entailed that in the second half of the 1940s, flats needed to be free from any ornamentation (Groys, 1992:p.90).

The common goal all over Europe was to institutionally solve the housing problem. The steps towards handling this problem can be seen after both world wars, and it was very practical to turn to the tools and form-language of modern architecture. This modern architecture continued in Western and Eastern-Europe as well, facilitating the process of reconstructing the destroyed urban areas. Architects summarised the new goals of the new situation in manifestos. The aim of architecture was seen to create a technical framework for a happier and more humane life (Groys, 1992:p.7).

As can be seen at the end of the 1940s, architectural tasks and goals were common across Europe. However, in the post-war situation, the role of politics had become more pronounced than ever before. The contrast between the Capitalist and the Socialist approaches was widening. The Stalinist principles emphasising form over function determined eastern Central European architecture. Socialist realist architecture was based on this idea and defined itself against the new modern architecture. The main purpose became to provide a dream world for the proletariat.

"Socialist Realism was created in order to hide the reality, to construct a beautiful illusion and present it as the truth [...] The task of the writer or artist consisted of creating such illusions, in depicting reality, not as it is, but as it will be under socialism; moreover, the future was described as if it already existed." (Petrov, 2011:p.874)

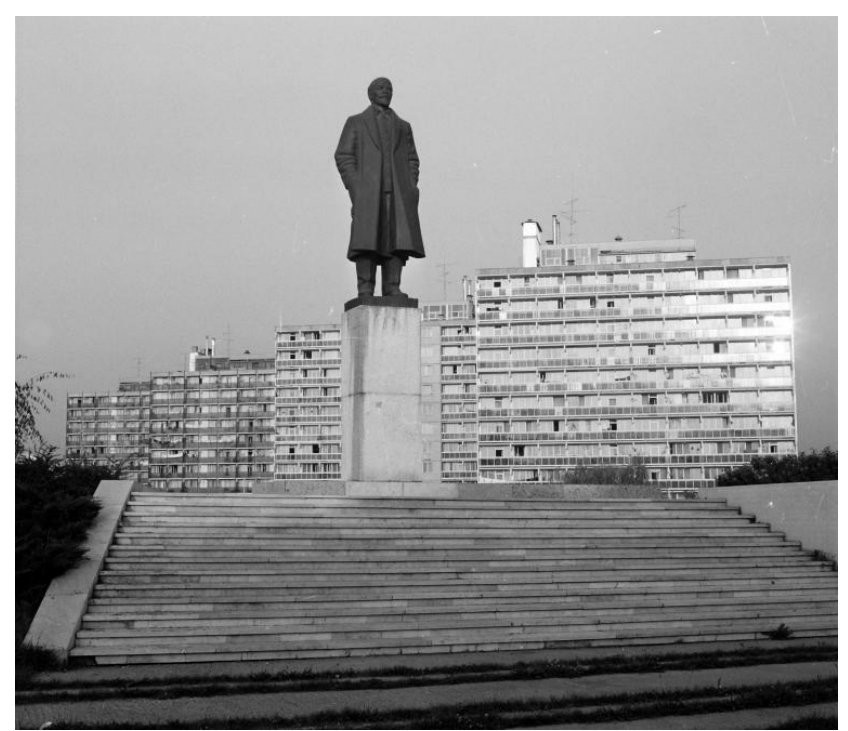

Fig. 1 Lenin sculpture in front of a Soviet modern housing estate in Zalaegerszeg in 1990. Source: Fortepan 116059.

Bernard Huet wrote that "Architecture is not fascist or Stalinist in its 'form'. There is only architecture of the fascist or Stalinist period". (Huet, 1998:p.254) The aim of socialist realism was not to express or present reality but to create the appearance or illusion of a false reality. This is the reason why socialist realism is not a style but a building method, which is determined by the formalism-debate in the era of dictatorship. The so-called 'realism-debate' in literature right after WW2 had the same stakes as the 'formalism-debate' several years later in architecture. The application of socialist realist tenets to the form-language of architecture was a slow and problematic process. The aim was to fight against the individualism of modernism and to create a new form of humanism [Homo Sovieticus]. This was based on Lenin's ideas of collective social consciousness, class struggle, the importance of cultural and national heritage, and a need for a positive hero (Cooke, 1997).

"Socialist Realism is an artistic procedure whose essence consists in reflecting reality captured in its revolutionary development, in a truthful and historically concrete way. It demands that the artist realize a definite aim [...] the formation of the new man in whom ideological wealth, spiritual beauty, and physical perfection coexist harmoniously". (Huet, 1998:p.257) This was expressed by the second sentence of Stalin's famous statement, which is not often quoted: "Socialist architecture is socialist for the content, nationalist for the form. Its national form rests on the development of national traditions and not on a mechanistic or intuitive explanation." (Huet, 1998:p.257) Thus, as we 
will see below, architecture tended to demonstrate the absolute superiority of the renewed neoclassicism (see Fig. 2, the railway station of Stalin city in Hungary in 1952).

For instance, after the 'great architectural debate' between form and function in 1951 in Hungary, socialist realism gained a new motto: socialist by content, national by form. To be socialist meant to care about humankind and to glamorise the victory of the proletariat. To be national meant that certain kinds of architectural styles needed to be chosen, which revoked national consciousness and the most glorious age of the socialist country (Molnár, 2013:p.74).

In Hungary, the socialist content was not questionable; to this end, the classicism of the so-called 'reform era' of the $19^{\text {th }}$ century was the preferred architectural form. In 1951, Máté Major summarised the new perspectives of the national and socialist architecture in three points. These were seen to be equally valid for every socialist country. [1] Architects must resist the coercion of Western forms of architecture, [2] solutions to the problems of national architectural traditions need to be developed and [3] it is necessary to recognise the presence of the great Soviet architecture and its rich architectural past. This entailed breaking away from the modern architectural theorems of Le Corbusier. According to Major, modern architecture became the servant of capitalism, neglecting also the importance of the class struggle ${ }^{1}$. Major's text is an original source for understanding the connection between ideology and architecture in the socialist countries after WW2. From his three points, it is also clear that he considered socialist realist architecture to be a method, not a style, for none of them contains any reference to a special form-language. This observation is also reinforced by Huet and Cook, who point out that the strong ideological and myth-creating content of socialist realism is understandable not as a style, but only as a method (Cooke, 1997:p.144).

Stalin's glamour project was based on the medieval heritage of Russian culture and the era of classicism in the $19^{\text {th }}$ century when the origin of what later became the Soviet national spirit was formed. The glamour project meant a clear architectural form-language and an ability to adapt to the needs of the Soviet age; the ideology, the myth and the adapted functionality worked together. Grandiose architectural gestures reminded people of this heritage in the case of individual buildings as well as complete

1 In Marxist ideology the conflict of interests between the workers and the ruling class in a capitalist society, regarded as inevitably violent.

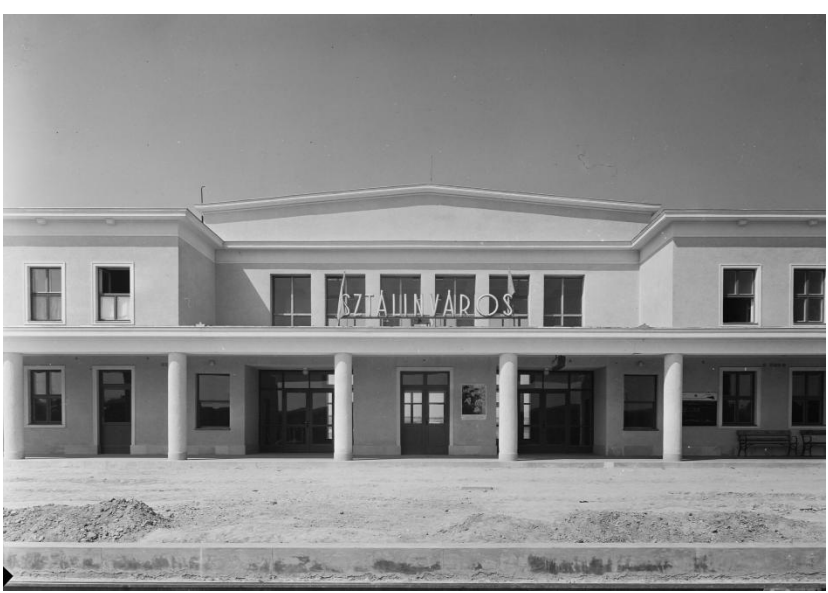

Fig. 2 The socialist realist railway station in Stalin city [Dunaújváros] in 1952. Source: Fortepan 02895

cities. Axial symmetry, huge columns, cour d'honneur, realistic sculptures and frescos, motifs from Antiquity all constituted the visual tools, which forcefully communicated the power of the totalitarian regime. These components together formed the Soviet type of 'total work of art' [Gesamtkunstwerk] (Groys, 1992:pp.52-53).

Façadism in these cases may be observed in the following cases. Socialist realist public buildings (similarly to baroque castles) are organised around representative halls. On the decorative forefront, there are motifs from ancient Roman and Greek art and architecture. Décor elements are made of prefabricated stucco or cast stone. In case of residential buildings, the balance between functionality and the decorative forefront was less pronounced than in public buildings. Houses were built with palace façades with all the problems and difficulties entailed by decorativity. Separate toilets and bathrooms, and rooms with separate entrances were abolished. Architects also returned to the equal window layout system.

To summarise, socialist realism means a step backwards to the architecture of historicism and secession to the less functional approaches already criticised by Adolf Loos in his Ornament and Crime in 1908. By the lack of functionality, the socialist realist building method dismissed most of the results of the modern movement (Loos, 1971:pp.19-24). ${ }^{2}$

\section{Socialist Realism in City Planning}

City planning was a typical socialist realist genre. A total socialist reconstruction in eastern and central European capital cities took place (e. g. Moscow, East-Berlin, Warsaw,

2 Loos gave a lecture with the German title 'Ornament und Verbrechen' in 1908, and it was first published in Cahiers d'aujourd'hui in 1913. 
Sofia, Bucharest and partly in Budapest). New socialist cities appeared, such as Stalin City in Hungary in 1952 (parallel to Stalingrad in the USSR). The city was first planned in modern style by the ex-Bauhaus student, Tibor Weiner. Because of the architectural paradigm shift discussed earlier, the whole city was built with representative avenues and 'closed-row-built' houses (Josephson, 2010:p.84).

As can be seen, the situation is also the same in the case of houses and cities. Laypeople, and often specialists as well, do not realise the difference between socialist realist urban planning and the late modern house block building districts; thus, we need to distinguish among the different levels of Soviet-type urban design. [1] The first phase of this was the original Stalinist approach in the Soviet Union. [2] The second era of this process emerged right after WW2 and was closely related to the reconstruction of bombed cities, such as Warsaw, which were not rebuilt as they existed before their destruction. [3] The third level is the short-lived 'applied' socialist realist era, which was terminated by the famous speech of Khrushchev on $31^{\text {st }}$ December 1954. A prominent example for this nation specific applied socialist realism is Stalin City [Dunaújváros] in Hungary. [4] Lastly, is the period of precast house block systems, which have been widely utilised around the world, even today (Prakfalvi, 1999:p.56).

Concerning the first period, it is important to note that, in 1934, Stalin defined the main goal of socialist city planning as follows: "It is not the external efficacy but the inner content which gives the good expression of good urban design." (Kolin, 1951:pp.3-4) Accordingly, the ideal socialist realist city was built from the bottom up, having 'neighbourhood units' as its basic constituting element with social content. The organising principle of these special districts was having a strong ideological base, and district-specific educational institutions served this function. This may be called the 'community machine' after Le Corbusier's 'house machine'. However, the socialist realist city filled the modernist form below the surface with its socialist content.

According to the cost-efficient approach, economical implementation became more important. After the Khrushchevian turn, new trends inevitably arose in city planning as well; socialist realist architects returned to the modern elements of Le Corbusier's architecture theory and practice, mainly for its economic solutions.

\section{The Radiant Future}

Due to the use of concrete panel house blocks, the socialist realist aesthetic culture and framework disappeared under
Khrushchev. After the death of Stalin (1953), the future of architecture was redefined in the Soviet Union. The new era started with Khrushchev's famous speech in 1954 to the Congress of Soviet Builders.

Soviet-style urban planning, unlike the urban development in western countries, meant the complete redesigning of cities. Soviet-style cities were standardised, mass-produced, and built in a short period of time. Before the wellknown house block era, there was an interesting 'experimental housing' project to work out optimal housing solutions in socialist countries; the old Buda district in the Hungarian capital (Branczik-Keller, 2011). The precursor of these, with the new technology and the social approach, was the Weissenhof housing estate [Weissenhofsiedlung] in Stuttgart from 1927. The new architecture was propagated in brochures and exhibitions to promote the new lifestyle. These houses were made of cast concrete. Among others, the techniques of standardisation, typisation and built-in kitchens were exported to the Soviet Union.

"Extensive expansion of manufacture of prefabricated reinforced-concrete structures and parts will give enormous economic benefits. Our builders know that until recently there was debate over which of two paths we should take in construction - use of prefabricated structures or monolithic concrete. We shall not name names or reproach those workers who tried to direct our construction industry towards the use of monolithic concrete. I believe these comrades now realise themselves that the position they adopted was wrong. Now, though, it's clear to everyone, it seems, that we must proceed along the more progressive path - the path of using prefabricated reinforced-concrete structures and parts.” (Khrushchev, 1963:p.173)

By constructing the socialist experimental housing estates in the second half of the 1950s, architects focused on solving real problems with living conditions instead of serving propaganda. The three main issues were as follows; [1] housing shortage that led to overcrowding, [2] multifunctional rooms instead of rooms with separate functions, [3] two or more generations had to live together in the same flat. Instead of using architecture for propaganda purposes along the lines of socialist ideology, architects had the opportunity to concentrate on real-life problems pertaining to the living conditions of people.

Of course, the socialist ideological content and strong reference to the national heritage were still significant. The usage of concrete for the prefabricated panel constructions was technological and ideological as well. The ideological aspect was to distinguish socialist architecture from the 
typical Western materials of the Cold War: steel and glass. It is interesting to note that Khrushchev sent Soviet architects to Western Europe to study the precast concrete systems. The panel-technology made the process of building quicker and cheaper. The concrete as the liquid stone made the method of prefabrication possible (Forty, 2012:p.157).

It is important to remember that Western European countries had the same reasons to use the precast concrete panel systems. On the one hand, they wanted to accelerate the construction of new housing districts. On the other, they needed to create workplaces for the unskilled masses. For this latter purpose, it was better to have standardised processes in housing construction, instead of construction phases requiring different skilled labour. The use of concrete also had the same pragmatic grounding in the West, because with concrete, building was quicker, cheaper and it did not need skilled labour from the industry (for example, the construction of Óbuda, a district of the Hungarian capital, in 1970 Fig. 3). (Forty, 2012:p.159)

The task of the development of new neighbourhoods was to increase the housing capacity of cities. The new housing complexes were built in the suburban areas in both Western and Eastern Europe. As the idea of panel building technology came from Western Europe to the East and the Soviet Union as well, this required that socialist propaganda could favourably compare Western and Eastern living conditions. People in socialist countries lived in new panel houses with the same level of comfort as their Western counterparts (Forty, 2012:pp.160-164).

Of course, this propaganda was working, but from a different perspective than during the socialist realist era. Training films were produced about these house blocks in order to educate people about their new functions and the correct usage of them. A standard district consisted of high-rises and small-scale service units for practical purposes such as schools, supermarkets, and restaurants to be used by the whole community of inhabitants. In these, we can easily recognise the 'column city' formulated by Le Corbusier in his 'City of Tomorrow and its Planning': the Radiant City (Le Corbusier, 1987:p.19).

The housing blocks, with their uniform appearance, also expressed the fight against the irregularity of the individual needs. During the years of socialist realism, a unique look was only allowed in case of public buildings, in order to express the power of the state. Later, during the years of the Soviet modern style, all architectural forms of individualism had to be eliminated, and the new transition in housing with many economic factors had started (Tsenkova, 2000).

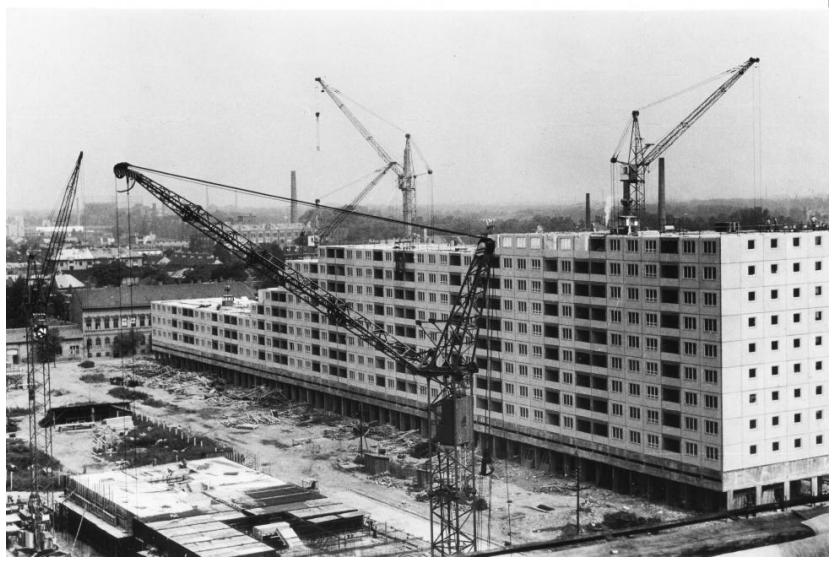

Fig. 3 Óbuda under construction in 1970. Source: Fortepan 74122.

\section{Conclusion}

This paper aims to show the transition from the modern architectural style of the interwar period through the socialist realism to the late/Soviet modern style after WW2. There are many similarities between the city of Le Corbusier's first machine age after WW1 and the prefabricated house block systems after WW2. In eastern-Central Europe, this continuous urban development was interrupted by a brief socialist realist gap (1951-1954).

Socialist realism was not a style, but a method. Its goal was to fight against the individualism of modernism and to create a new socialist humanism. The artistic and architectural ideology emphasised form against function. The form-language of architecture referred to the golden age of the nation with its historical ornaments on the surface, but below this, the buildings had modernist structure; this is called façadism. This glamour project was founded by Stalin and was developed into the Soviet 'total work of art' [Gesamtkunstwerk]. Urban design was a typical genre of socialist realism, which had different phases; [1] the original Stalinist approach, [2] the reconstruction after WW2, [3] versions applied to different socialist nations, and [4] the era of late/Soviet modern precast house block systems. The first three had a similar architectural form-language in urban design with required historical ornaments. Regarding their underlying structure, 'community machines' evolved. This can also be observed in the case of reconstructed (Moscow) and newly built (Stalin City in Hungary) cities.

After the Khrushchevian architectural turn (1954), architects could focus on the real-life problems of everyday people. A new era emerged: the period of prefabricated house block buildings, both in Western and Eastern Europe. There were common technological and ideological 
aims all over Europe; building new houses cost-effectively, creating workplaces for the unskilled masses and standardising the technological solutions.

The fight against the irregularity of individualism with the uniform appearance and universal greyness in urban design resulted in the Soviet-style modern 'column city', already envisioned by Le Corbusier in his City of To-morrow and Its Planning.

\section{References}

Branczik, M., Keller, M. (2011) "Korszerű lakás 1960: Az óbudai kísérlet" (Modernist Housing 1960: The Óbuda Experiment), Budapest Történeti Múzeum, Budapest.

Cooke, C. (1997) "Beauty as a Route to 'the Radiant Future': Responses of Soviet Architecture", Journal of Design History, 10(2), pp. 137-160. https://doi.org/10.2307/1316129

Forty, A. (2012) "Concrete and Culture", Reaktion Books Lts, London.

Groys, B. (1992) "The Total Art of Stalin: Avant-garde, Aesthetic Dictatorship, and Beyond", Princeton, New Jersey.

Huet, B. (1998) "Formalism-Realism", In: Hays, K. M. (ed.), Architecture Theory since 1968, The MIT Press, Cambridge, MA, pp. 254-260.

Josephson, P. R. (2010) "Would Trotsky Wear a Bluetooth? Technological Utopianism under Socialism", 1917-1989, Johns Hopkins University Press, Baltimore.

Khrushchev, N. (1963) "Industrialised Building Speech, 1954", In: Whitney T. P. (ed.), Khrushchev Speaks: Selected Speeches, Articles, and Press Conferences, 1949-1961 Ann Arbor, University of Michigan Press, pp. 153-192.

\section{Acknowledgement}

The project presented in this article is supported by ÚNKP17-3-III-BME-284 New National Excellence Program of the Ministry of Human Capacities.

Kolin (1951) "Sztálinváros szocialista város" (Stalin City is a Socialist City), Építés-Építészet, 1(1), pp. 3-4.

Le Corbusier (1987) "The City of To-morrow and Its Planning", Dover, New York.

Loos, A. (1971) "Ornament and Crime", In: Conrads, U. (ed.), Programs on Manifestoes on 20th-century Architecture, The MIT Press, Cambridge MA, pp. 19-24.

Molnár, V. (2013) "Building the State: Architecture, Politics, and State Formation in Post-War Central Europe", Routledge, Abingdon.

Petrov, P. (2011) "The Industry of Truing: Socialist Realism, Reality, Realization", Slavic Review, 70(4), pp. 873-892. https://doi.org/10.3917/vin.109.0072

Prakfalvi, E. (1999) "Architecture of Dictatorship: The Architecture of Budapest Between 1945 and 1959", The Mayor of Budapest, Budapest.

Tsenkova, S. (2000) "Housing in Transition and the Transition in Housing: The Experience of Central and Eastern Europe", Kapital Reklama, Sofia. 